\title{
Emerging principles of cancer biophysics
}

\author{
Woong Young So ${ }^{1} \quad$ Kandice Tanner ${ }^{1 *}$ \\ ${ }^{1}$ Laboratory of Cell Biology, Center for Cancer Research, National Cancer Institute, National Institutes of Health, Bethesda, MD, USA
}

\begin{abstract}
Cancer is a multi-step process where normal cells become transformed, grow, and may disseminate to establish new lesions within the body. In recent years, the physical properties of individual cells and the tissue microenvironment have been shown to be potent determinants of cancer progression. Biophysical tools have long been used to examine cell and tissue mechanics, morphology, and migration. However, exciting developments have linked these physical traits to gene expression changes that drive metastatic seeding, organ selectivity, and tumor growth. Here, we present some vignettes to address recent studies to show progress in harnessing biophysical tools and concepts to gain insights into metastasis.
\end{abstract}

\section{Keywords}

microenvironment, tissue biophysics, rheology

\section{Peer Review}

The peer reviewers who approve this article are:

1. Taher M Saif, Bioengineering, University of Illinois at Urbana-Champaign, United States Competing interests: No competing interests were disclosed.

2. Michelle R Dawson, Brown University, Department of Molecular Pharmacology, Physiology, and Biotechnology, Providence, Rhode Island, USA

Competing interests: No competing interests were disclosed.

\footnotetext{
*Corresponding author: Kandice Tanner (kandice.tanner@nih.gov)

Competing interests: The authors declare that they have no competing interests.

Grant information: This research was supported by the Intramural Research Program of the National Institutes of Health, the National Cancer Institute.

The funders had no role in study design, data collection and analysis, decision to publish, or preparation of the manuscript.

Copyright: $₫ 2021$ Tanner $\mathrm{K}$ et al. This is an open access article distributed under the terms of the Creative Commons Attribution License, which permits unrestricted use, distribution, and reproduction in any medium, provided the original work is properly cited.

How to cite this article: So WY and Tanner K. Emerging principles of cancer biophysics. Faculty Reviews 2021 10:(61) https://

doi. org/10.12703/r/10-61
}

Published: 27 July 2021, Faculty Reviews 10:(61) https://doi.org/10.12703/r/10-61 


\section{Introduction}

Cancer arises due to the acquisition of deleterious genetic events and environmental insults ${ }^{1}$. These transformative traits involve growth, migration, aberrant extracellular matrix (ECM) production, and phenotypic plasticity. Moreover, cancer cells can hijack normal stromal cells to aid survival ${ }^{1,2}$. These traits coupled with an acquired ability to evade immune surveillance present a formidable challenge against the goal of complete disease eradication". The "hallmarks of cancer" present these concepts as discretized critical elements required for establishment and progression of disease ${ }^{1}$. However, profound changes in the physical characteristics of tissues such as mechanical properties, cell shape, migration, and topographical cues often accompany these hallmarks. Changes in mechanical properties due to edema and de novo synthesis of ECM occur at the primary organ and at distant sites where lesions upset the homeostatic balance within the local microenvironment ${ }^{1-3}$. Stromal remodeling of fibrillar matrix components and neoangiogenesis alter the topographical cues. Finally, at the length scale of a single cell, shape and motility are distinct between normal and tumor phenotypes ${ }^{1}$. The importance of the biophysical cues in normal physiology cannot be understated, as studies have shown that cues such as rheological properties, shear forces due to fluid flow, and surface topography modulate how genes are activated and silenced in key processes involving growth, migration, invasion, and metabolism ${ }^{4-6}$. Preclinical models of pancreatic and breast cancer have shown that the stromal ECM microenvironment influences the therapeutic efficacy of chemotherapy, immunotherapy, and nanoparticle delivery at the primary $\operatorname{site}^{7-9}$. In the case of cancer, complementary dissection of the spatiotemporal dynamics of the alterations in biophysical properties along the metastatic cascade is needed to understand differences between indolent and aggressive disease, and also for treatment-responsive and refractory cancers.

\section{Biophysical cues in tumor metastasis}

Cells encounter diverse environmental cues as they transit through the circulatory system before arrest and entry into a distal organ ${ }^{10-14}$. During transit, cells are subjected to forces due to confined geometries and shear forces due to fluid transport of nutrients and exchange of wastes. These external cues can modulate cell shape and may irreversibly deform subcellular organelles such as the nucleus ${ }^{15-17}$. Tumor cells have distinct mechanical properties compared to those of normal cells ${ }^{15,18}$. Moreover, tumor cells are also influenced by the mechanical properties of the tissue at both the primary and the secondary sites ${ }^{10,19}$. A key question is how do tumor cells adapt to the difference in tissue mechanical properties. Tissue mechanics starts with the premise that individual cells and tissues can be mechanically defined by a combination of characteristics of viscous and elastic responses (viscoelasticity) on different length and time scales ${ }^{20-22}$. These physical properties are dynamically linked to alterations in strains, stresses, and osmotic pressures. Tissue geometry and composition are also important factors ${ }^{6,15,23}$. These physical changes have been linked to the modulation of epigenetic and genetic pathways that can influence metastatic potential ${ }^{17,24}$. In addition, tissue mechanics is in part dependent on the protein concentration, crosslinking, and microscale architecture of the ECM microenvironment ${ }^{2,12,25,26}$. Some exciting directions in the field of cancer biophysics have demonstrated that biophysical properties such as cell shape, mechanical phenotype, topography, hemodynamic forces, and pressure are important determinants of cancer progression ${ }^{12,15,23}$. In this commentary, we highlight recent work restricted to the last few years on highlighting the role of physical cues in cancer metastasis employing complex physiologically relevant models that recreate distinct environmental cues.

\section{Can we use single cell morphology to predict metastasis?}

Cell morphology has long been used as an important metric to diagnose cancers ${ }^{15}$. More recently, machine learning and digital pathology have simplified diagnostics where improved sensitivity allows for robust discrimination between subtypes of hematological cancers such as leukemias ${ }^{27}$. With respect to assessing metastasis, recent studies have highlighted that metrics such as cell morphology, mechanical phenotype, and migration might be predictive of invasion and metastatic potential for osteosarcomas and breast, pancreatic, and prostate cancers $^{28-30}$. One study using patient data further illustrated how single cell morphometrics combined with single cell transcriptomics could be predictive of metastasis. Using a combination of in vivo models, sophisticated imaging, and hierarchical cluster analysis, single cell morphologies were sufficient to predict the efficacy of tumor engraftment and metastasis in a human xenograft model of breast cancer in mice ${ }^{31}$. Simply, the examination of morphometrics such as nuclear and cell shape of single cell clones of a triple negative breast cancer cell line was sufficient to distinguish which features are predictive of key steps of the metastatic cascade such as intravasation (entry into circulation from primary site), extravasation (exit from circulation to secondary site), and outgrowth in the lung ${ }^{31}$. A correlation between transcriptome and morphology identified 155 genes that were confirmed to be correlated with metastasis and survival in a stratified patient cohort $^{31}$. However, further work will be needed to see if this data can be used to identify a signature that is conserved for other triple negative breast cancer cell lines and patient samples. As this technique can be applied to other tumor models of solid cancers, it provides a platform for further comparative studies. Moreover, it also has the potential to be combined at the time of biopsy where a primary tumor could be processed for single cell analysis. This is exciting, as one critical goal of precision medicine is the ability to predict, at the time of diagnosis, if in a given patient a primary tumor would advance to metastatic disease ${ }^{32-35}$.

\section{Can we use single cell mechanophenotype as a biomarker of pathology?}

Mechanical mapping of isogenic models of cancer progression has revealed that cancer cells are softer when compared to normal cells ${ }^{18}$. As cells need to detach and deform 
to enter and exit tissues, this softening has been postulated as a key step of metastasis. Thus, one approach is to determine if single cell mechanical phenotype can be predictive of metastatic potential ${ }^{25,36-38}$. One confounding issue is that the cellular mechanical properties depend on the length and temporal scales at which the measurements are performed. They are further dependent on experimental conditions, i.e. if measurements are performed on cells cultured in 2D versus 3D versus suspension, and the choice of matrices when embedded in a hydrogel ${ }^{18,39}$. Using a model of osteosarcoma, Holenstein et al. found that relative stiffness of the parental cancer clone compared to that of isogenic weakly and highly metastatic clones was heavily dependent on the technique employed ${ }^{40}$. At the nanometer scale, atomic force microscopy (AFM) measurements determined that the highly metastatic variant was softer when cultured on soft and stiff substrates for one pair of clones but showed the opposite trend for a second clone ${ }^{40}$. Microscale measurements using real-time deformability cytometry revealed that the metastatic clones were softer than the parental cancer clone when examined as a single cell suspension ${ }^{40}$. In these experiments, cellular deformation was used as a metric of stiffness. In a similar vein, recent work exploring a pair of metastatic and non-malignant clones and a pair of dormant and aggressive clones of a breast cancer progression series revealed that the microscale mechanics of both normal and cancer cells are heavily context dependent ${ }^{39}$. Using optical trap-based active microrheology, the authors found that cancer cells were stiffer than the normal counterpart when cultured in hydrogels of ECM similar to in vivo breast tissue ${ }^{39}$. However, relative stiffnesses varied when cultured in hydrogels of different types of ECM. These studies are heavily focused on relative stiffnesses, but more recent studies are exploring the full spectrum of rheological parameters where energy dissipation, viscosity, and power law dependence may strengthen the use of mechanical phenotype as a metric that more closely predicts metastatic potential.

\section{Can we use single cell mechanophenotype to understand drug resistance and organ selectivity?}

Within a primary tumor, tumor-initiating cells have also been implicated in drug resistance ${ }^{41,42}$. Intratumoral heterogeneity is also known to be an important factor in metastasis ${ }^{43}$. Moreover, if there is an associated risk of metastasis, advance knowledge of the potential site of the lesion would also be useful in personalized treatment. Using immortalized cell lines, multiple organ-seeking clones have been derived from the same parental cell line where preferential colonization of organs such as bone, brain, and lung is achieved when these clones are injected into mice ${ }^{34,35,44,45}$. These data suggest that individual phenotypes may encode for not only metastasis but also organ selectivity and drug resistance. One way of distinguishing these phenotypes may be defining single cell mechanical properties within a given immortalized cell line or patient-derived cells. Some preliminary data support this premise, as breast cancer cells that preferentially homed to lung and bone showed a differential migration and proliferation when cultured on substrates of different stiffnesses ${ }^{46}$. In addition, single cell mechanical phenotyping identified subpopulations of cells within a treatment-resistant line of patient-derived GBM cells ${ }^{47}$. An active area of research is to assess these phenotypes using multiple platforms such as AFM, Brillouin spectroscopy, and optical and magnetic tweezers in preclinical models ${ }^{12}$. In addition, magnetic resonance elastography and particle tracking microrheology have been recently demonstrated as viable modalities to probe cancer biomechanics in mice $^{48}$. However, it is critical to link these mechanical phenotypes to specific biological pathways. Thus, linking these techniques to other "omic" types of analysis is needed to refine our understanding of cancer mechanobiology as a biomarker for drug resistance and organ selectivity.

One salient factor is that cancer cells exist within an organ ecosystem where tumor cells actively recruit normal stromal cells via paracrine signals to aid tumor growth and dissemination $^{49,50}$. Within this milieu, dynamic and reciprocal interactions between individual cancer and stromal cells collectively drive phenotypic and genotypic changes as a function of tumor progression ${ }^{50}$. In addition, acellular components such as changes in ECM composition, concentration, and architecture are modulated by these de novo transformed stromal cells ${ }^{10,12,49,50}$. Infiltrating and resident immune cells and neovascularization are also potent regulators within the milieu $^{51}$. These modifications result in alterations in tissue mechanics, interstitial stresses, and aberrant tissue architecture $^{52}$. Specifically, in many solid tumors, cancer-associated fibroblasts (CAFs) stiffen the ECM microenvironment via secreted factors concomitantly with direct remodeling via contractile forces ${ }^{49,50}$. In breast, lung, and pancreatic cancers, molecular signatures have been identified to aid in the discernment of CAF subtypes ${ }^{50}$. Previous studies have shown that stromal and stem cells show a differential response to tumor-secreted factors $^{52}$. Thus, one idea is that molecular heterogeneities correlate with distinct mechanical phenotypes. Furthermore, a complementary strategy might involve mapping the mechanical properties of the transformed stromal cells in our efforts to understand disease progression.

\section{Can cell motility be a predictor of metastatic potential in preclinical models?}

As tumor cells leave the primary site, one key aspect of metastasis is persistent motility ${ }^{15}$. Multiple studies have looked at differential migration speeds, persistence, and displacement across different cancer lines ${ }^{15}$. The results have been mixed in terms of what is predictive of the establishment of a de novo lesion. One reason may be that recapitulating the complex environments of migrating disseminated cancer cells is key to establishing a migratory signature ${ }^{10}$. These environments include conduits such as lymphatic and blood vessels and interstitial tissues ${ }^{15,23}$. These conduits vary in widths, ranging from $10 \mathrm{~s}$ to $100 \mathrm{~s}$ of microns and curvatures, where surfaces may be linear, branched, or disordered ${ }^{23}$. Differential shear 
forces and drag due to fluid flow and glycocalyx on cell surfaces may also be potent factors ${ }^{23}$. Drawing on engineering principles, microfluidics, 3D biomimetic models, and animal models have been used to recreate the complexities, thus providing a platform to evaluate how distinct modes of migration are linked to metastatic potential. In recent work, a migratory signature predictive of metastatic potential was established for immortalized and patient-derived breast cancers using a microfluidics-based platform ${ }^{53}$. Cells were siloed into different categories based on the percentage of a given cell line that was highly migratory in the microfluidic device and a proliferative index based on the percentage of cells that were positive for Ki67 staining. These groups were then assessed for metastatic seeding and outgrowth in the lung, liver, and lymph nodes in mice following subcutaneous and tail vein injections. Complementary transcriptomic analysis revealed that the RAS/MAPK and PI3K pathways were key pathways underpinning this signature. In an effort to understand if therapeutics directed at minimizing migration are effective, the authors also employed microfluidics to screen the efficacy of trametinib (inhibitor of MEK1 and MEK2) and buparlisib (inhibitor of PI3K) in limiting the spread of breast cancer cell lines ${ }^{53}$. They determined that three triple negative breast cancer cell lines were less migratory when treated with trametinib. In contrast, a non-uniform result was obtained following treatment with buparlisib where an increase of migration in one cell line was observed. These data highlighted the fact that one drug does not affect all genotypes similarly for a given phenotype ${ }^{53}$. Moreover, it demonstrated that a "systems approach" in mitigating aberrant signaling might be needed for effective molecular targeting.

One factor that may be missing using in vitro biomimetics is the incorporation of physiological shear forces and cell types such as endothelial cells present in many vessel conduits in $v_{i v o}{ }^{23}$. However, single cell analysis remains technically challenging if visualization and characterization of transit within multiple organs and vascular systems are desired outcomes. Recently, the zebrafish has become useful to evaluate human xenografts of cancer cells in vivo. Moreover, patterns of metastasis of human tumors in mouse models are observed in zebrafish ${ }^{16,17}$. The size of zebrafish allows for larger sample sizes which are not readily feasible using mice. The optical properties of the zebrafish also affords the benefit of ease of use of optical-based techniques such as imaging and mechanical mapping. Recently, blood flow was shown to modulate the extravasation potential of human cancer cells in larval fish at the age where the size of blood vessels is comparable to mammalian capillaries ${ }^{54}$. Direct quantitation of the hemodynamic forces and the adhesion force to the luminal surfaces was performed using optical tweezers in this system $^{54}$. Importantly, cell receptors such as $\beta 1$ integrin were found to be important for "sensing" these external forces during extravasation. In addition to fluid flow, the architecture of the blood vessels was also shown to be an important factor in organ selection ${ }^{55}$. In larval zebrafish, organ selectivity of human breast cancer cell lines is driven by both vessel topography and cell type-dependent extravasation in the larval zebrafish ${ }^{55}$. Specifically, silencing of $\beta 1$ integrin, a key protein for mechanosensing, reduced extravasation in the bone marrow-seeking clone in the topographically complex vasculature of the zebrafish bone marrow niche. In contrast, silencing the same gene had no effect on the brain-homing clone; instead increased extravasation was observed in the topographically linear brain vasculature. Importantly, these studies belie the importance of external physical cues in regulating organ selection and extravasation, the caveat being that only if the tumor cells have the machinery to interpret these cues can physical properties influence cellular behavior ${ }^{55}$. They also show the importance of multiplexed analysis where biophysical phenotyping is performed in addition to transcriptomic and proteomic analysis. The model system has been used to assess effective therapeutics for patient-derived xenografts $^{56}$. However, elucidation of the role of physical cues in drug efficacy and ultimately a platform for personalized medicine is ongoing.

\section{Future perspectives: moving to the clinic}

In this commentary, we highlight only recent research reports focused on specific biophysical cues in preclinical models. One goal would be to continue to build on findings from basic science to provide a pipeline for clinical use. Many commonly employed diagnostic tools are rooted in our understanding of the interplay between light-tissue interactions and the mechanical properties of tissues ${ }^{26,38,57}$. Imaging modalities such as X-ray, optical coherence tomography, ultrasound, and magnetic resonance imaging are now routine in the clinic $^{57-59}$. These non-invasive techniques detect changes in optical and mechanical properties of tissue associated with disease ${ }^{57-59}$. Specifically, Fibroscan, an ultrasound-based modality, quantitates liver stiffness as a metric to differentiate normal from that of diseased phenotypes such as fibrotic (excess type I collagen deposition and scar formation) and steatosis (due to increase in adipose tissue) ${ }^{60,61}$. Within the framework of cancer, the mammogram, an X-ray-based modality, is routinely used as a screening tool of malignancy where cancer is optically and mechanically distinct from normal

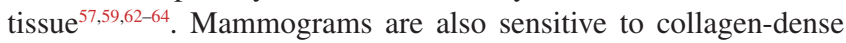
breasts, a feature that is associated with an increased risk of breast cancer ${ }^{64-67}$. These techniques are amenable to multiplexed analysis in combination with other platforms $s^{59,67,68}$. Not restricted to diagnosis in situ, ex vivo analysis of fresh or frozen tissue biopsies using techniques such as atomic force microscopy and optical and magnetic tweezers also supports the notion that tissue mechanics is a reliable hallmark of cancer $^{38,69-71}$. In a similar vein, preclinical analysis of additional biophysical properties can provide a framework that will provide insight into determinants of tumor etiology, cancer progression, and metastasis. These concepts are of critical importance for effective and durable treatment, especially in the event of metastatic disease. 
1. Whanahan D, Weinberg RA: Hallmarks of cancer: The next generation. Cell. 2011; 144(5): 646-74 PubMed Abstract | Publisher Full Text | Faculty Opinions Recommendation

2. Pickup MW, Mouw JK, Weaver VM: The extracellular matrix modulates the hallmarks of cancer. EMBO Rep. 2014; 15(12): 1243-53. PubMed Abstract | Publisher Full Text | Free Full Text

3. Maccarthy-Morrogh L, Martin P: The hallmarks of cancer are also the hallmarks of wound healing. Sci Signal. 2020; 13(648): eaay8690. PubMed Abstract | Publisher Full Text | Faculty Opinions Recommendation

4. Park JS, Burckhardt CJ, Lazcano R, et al:: Mechanical regulation of glycolysis via cytoskeleton architecture. Nature. 2020; 578(7796): 621-626. PubMed Abstract | Publisher Full Text | Free Full Text | Faculty Opinions Recommendation

5. Ladoux B, Mège RM: Mechanobiology of collective cell behaviours. Nat Rev Mol Cell Biol. 2017; 18(12): 743-757.

PubMed Abstract | Publisher Full Text

6. C Chaudhuri O, Cooper-White J, Janmey PA, et al.: Effects of extracellular matrix viscoelasticity on cellular behaviour. Nature. 2020; 584(7822): 535-546. PubMed Abstract | Publisher Full Text | Free Full Text | Faculty Opinions Recommendation

7. N Sindhwani S, Syed AM, Ngai J, et al:: The entry of nanoparticles into solid tumours. Nat Mater. 2020; 19(5): 566-575. PubMed Abstract | Publisher Full Text | Faculty Opinions Recommendation

8. Vennin C, Murphy KJ, Morton JP, et al:: Reshaping the Tumor Stroma for Treatment of Pancreatic Cancer. Gastroenterology. 2018; 154(4): 820-838. PubMed Abstract | Publisher Full Text | Faculty Opinions Recommendation

9. Nakasone ES, Askautrud HA, Kees T, et al:: Imaging tumor-stroma interactions during chemotherapy reveals contributions of the microenvironment to resistance. Cancer Cell. 2012; 21(4): 488-503. PubMed Abstract | Publisher Full Text | Free Full Text | Faculty Opinions Recommendation

10. Kim J, Tanner K: Recapitulating the Tumor Ecosystem Along the Metastatic Cascade Using 3D Culture Models. Front Oncol. 2015; 5: 170 . PubMed Abstract | Publisher Full Text | Free Full Text

11. Kumar S, Weaver VM: Mechanics, malignancy, and metastasis: The force journey of a tumor cell. Cancer Metastasis Rev. 2009; 28(1-2): 113-27. PubMed Abstract | Publisher Full Text | Free Full Text

12. Tanner K: Perspective: The role of mechanobiology in the etiology of brain metastasis. APL Bioeng. 2018; 2(3): 031801. PubMed Abstract | Publisher Full Text | Free Full Text

13. C Spill F, Reynolds DS, Kamm RD, et al:: Impact of the physical microenvironment on tumor progression and metastasis. Curr Opin Biotechnol. 2016; 40: 41-48.

PubMed Abstract | Publisher Full Text | Free Full Text |

Faculty Opinions Recommendation

14. Paul $C D$, Mistriotis $P$, Konstantopoulos $K$ : Cancer cell motility: Lessons from migration in confined spaces. Nat Rev Cancer. 2017; 17(2): 131-40. PubMed Abstract | Publisher Full Text | Free Full Text

15. Wirtz D, Konstantopoulos K, Searson PC: The physics of cancer: The role of physical interactions and mechanical forces in metastasis. Nat Rev Cancer. 2011; 11(7): 512-22.

PubMed Abstract | Publisher Full Text | Free Full Text

16. Denais $\mathrm{CM}$, Gilbert RM, Isermann $\mathrm{P}$, et al:: Nuclear envelope rupture and repair during cancer cell migration. Science. 2016; 352(6283): 353-8. PubMed Abstract | Publisher Full Text | Free Full Text | Faculty Opinions Recommendation

17. N Nava MM, Miroshnikova YA, Biggs LC, et al:: Heterochromatin-Driven Nuclear Softening Protects the Genome against Mechanical Stress-Induced Damage. Cell. 2020; 181(4): 800-817.e22. PubMed Abstract | Publisher Full Text | Free Full Text | Faculty Opinions Recommendation

18. - Wu PH, Aroush DRB, Asnacios A, et al:: A comparison of methods to assess cell mechanical properties. Nat Methods. 2018; 15(7): 491-498. PubMed Abstract | Publisher Full Text | Free Full Text | Faculty Opinions Recommendation

19. Bissell MJ, Hines WC: Why don't we get more cancer? A proposed role of the microenvironment in restraining cancer progression. Nat Med. 2011; 17(3): $320-9$.

PubMed Abstract | Publisher Full Text | Free Full Text

20. Storm C, Pastore JJ, MacKintosh FC, et al.: Nonlinear elasticity in biological gels. Nature. 2005; 435(7039): 191-4. PubMed Abstract | Publisher Full Text
21. Janmey PA, McCulloch CA: Cell mechanics: Integrating cell responses to mechanical stimuli. Annu Rev Biomed Eng. 2007; 9: 1-34. PubMed Abstract | Publisher Full Text

22. Katira P, Bonnecaze RT, Zaman MH: Modeling the mechanics of cancer: Effect of changes in cellular and extra-cellular mechanical properties. Front Oncol. 2013; 3: 145.

PubMed Abstract | Publisher Full Text | Free Full Text

23. Follain G, Herrmann D, Harlepp S, et al.: Fluids and their mechanics in tumour transit: Shaping metastasis. Nat Rev Cancer. 2020; 20(2): 107-124. PubMed Abstract | Publisher Full Text | Faculty Opinions Recommendation

24. Pfeifer CR, Vashisth M, Xia Y, et al.: Nuclear failure, DNA damage, and cell cycle disruption after migration through small pores: A brief review. Essays Biochem. 2019; 63(5): 569-577.

PubMed Abstract | Publisher Full Text | Faculty Opinions Recommendation

25. Discher D, Dong C, Fredberg JJ, et al.: Biomechanics: Cell research and applications for the next decade. Ann Biomed Eng. 2009; 37(5): 847-59. PubMed Abstract | Publisher Full Text | Free Full Text

26. Ariza de Schellenberger J, Bergs I, Taupitz SM: "The Extracellular Matrix as a Target for Biophysical and Molecular Magnetic Resonance Imaging". in Quantification of Biophysical Parameters in Medical Imaging, I. Sack, T. Schaeffter, Eds. (Springer International Publishing, Cham), 2018; 123-150. Eds. (Springer Intern

27. Radakovich N, Nagy M, Nazha A: Machine learning in haematological malignancies. Lancet Haematol. 2020; 7(7): e541-e550. PubMed Abstract | Publisher Full Text | Faculty Opinions Recommendation

28. Haffner MC, Esopi DM, Chaux A, et al.: AIM1 is an actin-binding protein that suppresses cell migration and micrometastatic dissemination. Nat Commun. 2017; 8(1): 142

PubMed Abstract | Publisher Full Text | Free Full Text

29. Lyons SM, Alizadeh E, Mannheimer J, et al:: Changes in cell shape are correlated with metastatic potential in murine and human osteosarcomas. Biol Open. 2016; 5(3): 289-99.

PubMed Abstract | Publisher Full Text | Free Full Text

30. Wu PH, Phillip JM, Khatau SB, et al:: Evolution of cellular morpho-phenotypes in cancer metastasis. Sci Rep. 2015; 5: 18437.

PubMed Abstract | Publisher Full Text | Free Full Text

31. Wu PH, Gilkes DM, Phillip JM, et al.: Single-cell morphology encodes metastatic potential. Sci Adv. 2020; 6(4): eaaw6938. PubMed Abstract | Publisher Full Text | Free Full Text Faculty Opinions Recommendation

32. Arnedos M, Vicier C, Loi S, et al.: Precision medicine for metastatic breast cancer--limitations and solutions. Nat Rev Clin Oncol. 2015; 12(12): 693-704. PubMed Abstract | Publisher Full Text

33. Morris AH, Orbach SM, Bushnell GG, et al.: Engineered Niches to Analyze Mechanisms of Metastasis and Guide Precision Medicine. Cancer Res. 2020; 80(18): 3786-3794.

PubMed Abstract | Publisher Full Text | Free Full Text |

Faculty Opinions Recommendation

34. Nguyen DX, Bos PD, Massagué J: Metastasis: From dissemination to organ-specific colonization. Nat Rev Cancer. 2009; 9(4): 274-84. PubMed Abstract | Publisher Full Text

35. Obenauf AC, Massagué J: Surviving at a Distance: Organ-Specific Metastasis. Trends Cancer. 2015; 1(1): 76-91. PubMed Abstract | Publisher Full Text | Free Full Text

36. Lampi MC, Reinhart-King CA: Targeting extracellular matrix stiffness to attenuate disease: From molecular mechanisms to clinical trials. Sci Trans Med. 2018; 10(422): eaao0475.

PubMed Abstract | Publisher Full Text | Faculty Opinions Recommendation

37. Alibert C, Goud B, Manneville JB: Are cancer cells really softer than normal cells? Biol Cell. 2017; 109(5): 167-89.

PubMed Abstract | Publisher Full Text

38. Plodinec M, Loparic M, Monnier CA, et al:: The nanomechanical signature of breast cancer. Nat Nanotechnol. 2012; 7(11): 757-65.

PubMed Abstract | Publisher Full Text

39. Staunton JR, So WY, Paul CD, et al:: High-frequency microrheology in 3D reveals mismatch between cytoskeletal and extracellular matrix mechanics. Proc Natl Acad Sci U S A. 2019; 116(29): 14448-55 PubMed Abstract | Publisher Full Text | Free Full Text

40. Holenstein CN, Horvath A, Schär B, et al.: The relationship between metastatic potential and in vitro mechanical properties of osteosarcoma cells. Mol Biol Cell. 2019; 30(7): 887-98. PubMed Abstract | Publisher Full Text | Free Full Text | Faculty Opinions Recommendation 
41. Tanner K, Gottesman MM: Beyond 3D culture models of cancer. Sci Trans/ Med. 2015; 7(283): 283ps9.

PubMed Abstract | Publisher Full Text | Free Full Text

42. Dean M, Fojo T, Bates S: Tumour stem cells and drug resistance. Nat Rev Cancer. 2005; 5(4): 275-84.

PubMed Abstract | Publisher Full Text

43. Fidler IJ: Tumor heterogeneity and the biology of cancer invasion and metastasis. Cancer Res. 1978; 38(9): 2651-60. PubMed Abstract

44. Bos PD, Zhang XHF, Nadal C, et al.: Genes that mediate breast cancer metastasis to the brain. Nature. 2009; 459(7249): 1005-9. PubMed Abstract | Publisher Full Text | Free Full Text | Faculty Opinions Recommendation

45. Nguyen DX, Massagué J: Genetic determinants of cancer metastasis. Nat Rev Genet. 2007: 8(5): 341-52. PubMed Abstract | Publisher Full Text

46. Kostic A, Lynch CD, Sheetz MP: Differential matrix rigidity response in breast cancer cell lines correlates with the tissue tropism. PLoS One. 2009; 4(7): e6361.

PubMed Abstract | Publisher Full Text | Free Full Text

47. Foss A, Zanoni M, So WY, et al:: Patient-derived glioblastoma cells (GBM) exhibit distinct biomechanical profiles associated with altered activity in the cytoskeleton regulatory pathway. bioRxiv. 2020; 2020.2007.2016.207233. Publisher Full Text

48. Streitberger KJ, Lilaj L, Schrank F, et al:: How tissue fluidity influences brain tumor progression. Proc Natl Acad Sci U S A. 2020; 117(1): 128-34. PubMed Abstract | Publisher Full Text | Free Full Text | Faculty Opinions Recommendation

49. CEmon B, Bauer J, Jain Y, et al.: Biophysics of Tumor Microenvironment and Cancer Metastasis - A Mini Review. Comput Struct Biotechnol J. 2018; 16: 279-87.

PubMed Abstract | Publisher Full Text | Free Full Text | Faculty Opinions Recommendation

50. Barbazán J, Matic Vignjevic D: Cancer associated fibroblasts: Is the force the path to the dark side? Curr Opin Cell Biol. 2019; 56: 71-9. PubMed Abstract | Publisher Full Text | Faculty Opinions Recommendation

51. Maller O, Drain AP, Barrett AS, et al:: Tumour-associated macrophages drive stromal cell-dependent collagen crosslinking and stiffening to promote breast cancer aggression. Nat Mater. 2021; 20(4): 548-59. PubMed Abstract | Publisher Full Text | Free Full Text | Faculty Opinions Recommendation

52. Nia HT, Munn LL, Jain RK: Physical traits of cancer. Science. 2020 370(6516): eaaz0868

PubMed Abstract | Publisher Full Text | Free Full Text | Faculty Opinions Recommendation

53. CYankaskas $\mathrm{CL}$, Thompson $\mathrm{KN}$, Paul CD, et al:: A microfluidic assay for the quantification of the metastatic propensity of breast cancer specimens. Nat Biomed Eng. 2019; 3(6): 452-65 PubMed Abstract | Publisher Full Text | Free Full Text | Faculty Opinions Recommendation

54. Collain G, Osmani N, Azevedo AS, et al:: Hemodynamic Forces Tune the Arrest, Adhesion, and Extravasation of Circulating Tumor Cells. Dev Cell. 2018; 45(1): 33-52.e12.

PubMed Abstract | Publisher Full Text | Faculty Opinions Recommendation

55. Paul CD, Bishop K, Devine A, et al.: Tissue Architectural Cues Drive Organ Targeting of Tumor Cells in Zebrafish. Cell Syst. 2019; 9(2): 187-206.e16. PubMed Abstract | Publisher Full Text | Free Full Text
56. Yyan C, Brunson DC, Tang Q, et al:: Visualizing Engrafted Human Cancer and Therapy Responses in Immunodeficient Zebrafish. Cell. 2019; 177(7): 1903-1914.e14.

PubMed Abstract | Publisher Full Text | Free Full Text |

Faculty Opinions Recommendation

57. Grosenick D, Rinneberg H, Cubeddu R, et al.: Review of optical breast imaging and spectroscopy. J Biomed Opt. 2016; 21(9): 91311. PubMed Abstract | Publisher Full Text

58. Kevles BH: Naked to the Bone: Medical Imaging in the Twentieth Century. Rutgers University Press, 1997; 88(4). Publisher Full Text

59. W Waterhouse DJ, Fitzpatrick CRM, Pogue BW, et al:: A roadmap for the clinical implementation of optical-imaging biomarkers. Nat Biomed Eng. 2019 3(5): 339-53.

PubMed Abstract | Publisher Full Text | Faculty Opinions Recommendation

60. Afdhal NH: Fibroscan (transient elastography) for the measurement of liver fibrosis. Gastroenterol Hepatol (N Y). 2012; 8(9): 605-7. PubMed Abstract | Free Full Text

61. Wong GLH: Update of liver fibrosis and steatosis with transient elastography (Fibroscan). Gastroenterol Rep (Oxf). 2013; 1(1): 19-26. PubMed Abstract | Publisher Full Text | Free Full Text

62. Lee CS, Sickles EA, Moy L: Risk Stratification for Screening Mammography: Benefits and Harms. AJR Am J Roentgenol. 2019; 212(2): 250-8. PubMed Abstract | Publisher Full Text | Faculty Opinions Recommendation

63. Yu J, Nagler RH, Fowler EF, et al: Women's Awareness and Perceived Importance of the Harms and Benefits of Mammography Screening: Results From a 2016 National Survey. JAMA Intern Med. 2017; 177(9): 1381-2. PubMed Abstract | Publisher Full Text | Free Full Text

64. Boyd NF, Li Q, Melnichouk O, et al.: Evidence that breast tissue stiffness is associated with risk of breast cancer. PLoS One. 2014; 9(7): e100937. PubMed Abstract | Publisher Full Text | Free Full Text

65. Northey JJ, Barrett AS, Acerbi I, et al:: Stiff stroma increases breast cancer risk by inducing the oncogene ZNF217. J Clin Invest. 2020; 130(11): 5721-37. PubMed Abstract | Publisher Full Text | Free Full Text Faculty Opinions Recommendation

66. Li T, Sun L, Miller N, et al: The association of measured breast tissue characteristics with mammographic density and other risk factors for breast cancer. Cancer Epidemiol Biomarkers Prev. 2005; 14(2): 343-9. PubMed Abstract | Publisher Full Text

67. Pinkert MA, Salkowski LR, Keely PJ, et al:: Review of quantitative multiscale imaging of breast cancer. J Med Imaging (Bellingham). 2018; 5(1): 10901. PubMed Abstract | Publisher Full Text | Free Full Text | Faculty Opinions Recommendation

68. Sack I, Schäffter T: Quantification of Biophysical Parameters in Medical Imaging. Springer International Publishing, 2018; 1. (VIII, 497 pages 178 illustrations, 130 illustrations in color). Publisher Full Text

69. Cross SE, Jin YS, Rao J, et al:: Nanomechanical analysis of cells from cancer patients. Nat Nanotechnol. 2007; 2(12): 780-3. PubMed Abstract | Publisher Full Text

70. Acerbi I, Cassereau L, Dean I, et al.: Human breast cancer invasion and aggression correlates with ECM stiffening and immune cell infiltration. Integr Biol (Camb). 2015; 7(10): 1120-34. PubMed Abstract | Publisher Full Text | Free Full Text | Faculty Opinions Recommendation

71. Staunton JR, Vieira W, Fung KL, et al.: Mechanical properties of the tumor stromal microenvironment probed in vitro and ex vivo by in situ-calibrated optical trap-based active microrheology. Cell Mol Bioeng. 2016; 9(3): 398-417. PubMed Abstract | Publisher Full Text | Free Full Text 